Proc. Estonian Acad. Sci. Biol. Ecol., 2006, 55, 3, 199-215

\title{
Macroflora in Lake Ülemiste (Estonia) - changes and the impact of environmental factors
}

\author{
Tiiu Trei $^{\mathrm{a}^{\mathrm{*}}}$ and Tiia Pedusaar ${ }^{\mathrm{b}}$ \\ a Institute of Agricultural and Environmental Sciences, Centre for Limnology, Estonian University \\ of Life Sciences, Riia 181, 51014 Tartu, Estonia \\ b Tallinn Water Ltd., Ädala 10, 10614 Tallinn, Estonia; tiia.pedusaar@tvesi.ee \\ Received 27 January 2005, in revised form 15 November 2005
}

\begin{abstract}
The changes in the macroflora observed over the last 100 years in Lake Ülemiste in the vicinity of Tallinn and the impact of environmental factors are reported. Lake Ülemiste has supplied the city of Tallinn with water since the 14th century, but the treatment of water did not start until 1927. The macroflora of Lake Ülemiste has been studied four times during the 20th century: in 1908, 1968,1979 , and 2000, with additions in 2004. The extent of macrophyte cover and the maximum width of the zone of macrophytes have reduced in the course of 100 years. While the species composition has not changed in most of the lake, the relationships between dominating species have altered. In 2000, Phragmites australis was the predominant species in the lake, whereas Scolochloa festucacea was the main dominant in 1908. The widely fluctuating water level, as well as steadily increasing mean annual water level since the beginning of the 1960s, favoured a decline in the macrophyte community by the end of the 20 th century.
\end{abstract}

Key words: macrophytes, environmental factors, Lake Ülemiste, Estonia.

\section{INTRODUCTION}

Lake Ülemiste has been and still is the most intensively exploited waterbody in Estonia. The lake has supplied Tallinn, the capital of Estonia, with water since the 14th century. The treatment of water started in 1927. Presently Tallinn Water Ltd. treats water to supply over 400000 customers. Problems with inadequate water quality had, however, already risen by the end of the 19th century because of frequent blooms of cyanobacteria in the lake. The first proper study of the macrophytes of Lake Ülemiste was published by Schneider in 1908. The macroflora of the lake was again investigated in the second half of the century by Pork (1968) and by Mäemets (1979). The main macrophyte surveys for the present

\footnotetext{
* Corresponding author, tiiu.trei@zbi.ee
} 
study were carried out in 2000 and in 2004. These investigations enabled us to make some comparisons of macroflora and vegetation during the 20th century. However, earlier studies were descriptive and provided very little quantitative information. Water level and underwater light conditions are regarded as environmental factors affecting the macrophytes in the lake.

\section{STUDY AREA}

Lake Ülemiste $\left(59^{\circ} 24^{\prime} 1^{\prime \prime}\right.$ and $\left.24^{\circ} 45^{\prime} 48^{\prime \prime}\right)$ is an urban, shallow and eutrophic lake. Its water level is regulated via the man-made Pirita-Ülemiste Canal (Fig. 1), which was built in 1922 and has an outflow to the plant and an emergency outlet to the sea. The lake borders on the city of Tallinn. Tallinn Airport is located on its north-east shore, and the main highway as well as the railway connecting the

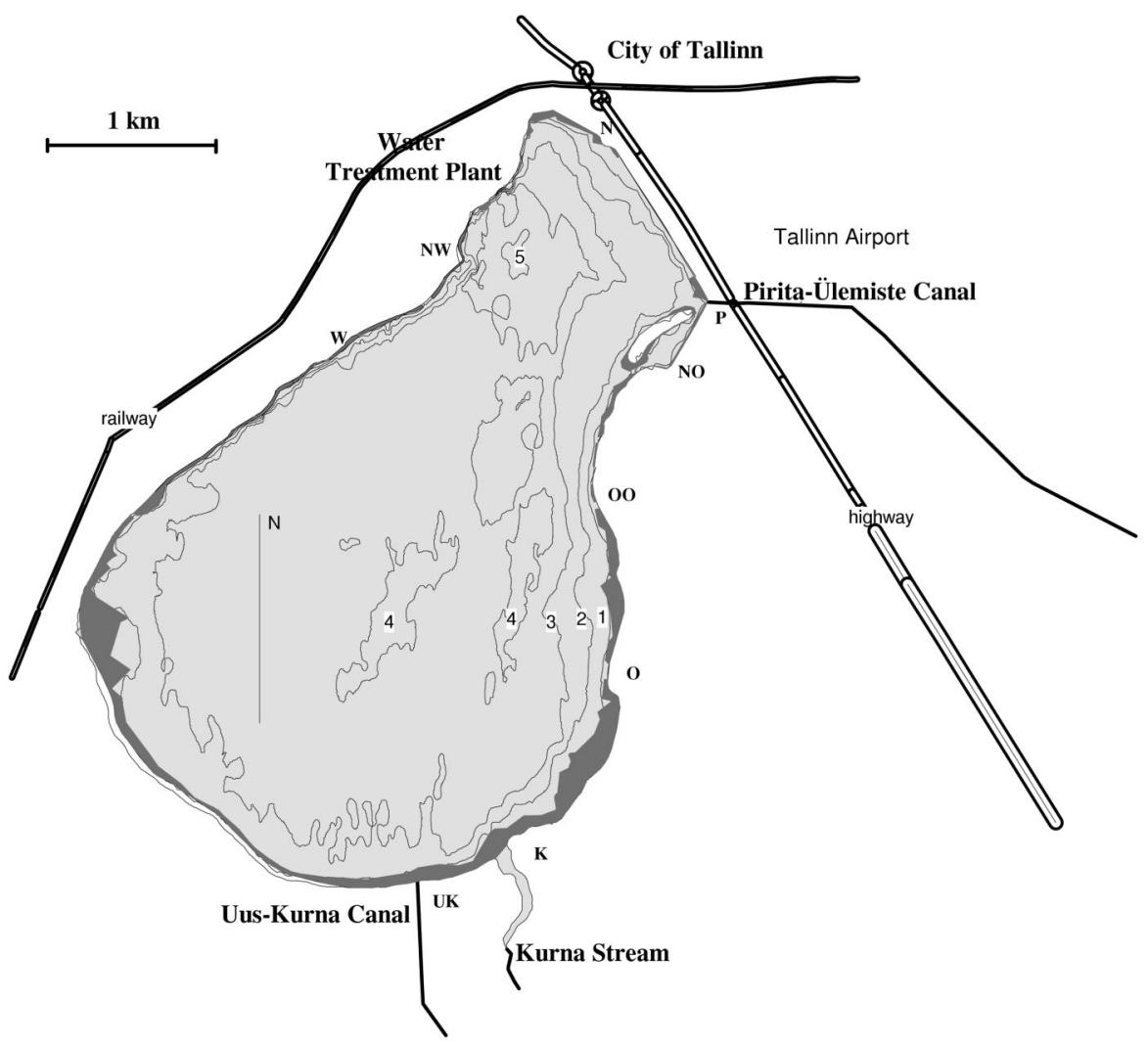

Fig. 1. Bathymetric map of Lake Ülemiste with the area covered by macrophytes (dark gray). The following non-typical sites in the lake in 2000 are shown: $\mathrm{N}$ and $\mathrm{OO}$ - shallow areas $(0.1-0.7 \mathrm{~m})$ with specific submersed vegetation, $\mathrm{P}$ - Pirita-Ülemiste Canal, NO - sheltered inlet, $\mathrm{O}$ - quagmire, $\mathrm{K}$ - Kurna Stream, UK - Uus-Kurna Canal, W - small island, NW - small round inlet. 1-5 isolines ( $1 \mathrm{~m}, 2 \mathrm{~m}$, etc.). 
north and south of Estonia pass very close to the lake. The pressure of building development close to the lake itself has increased since the beginning of the 1990s. No recreational activity is allowed on Lake Ülemiste as it serves as a raw water supply.

The hydrological regime of the lake varied greatly during the 20th century (Table 1 and Fig. 2). The catchment area was enlarged from 79 to $1865 \mathrm{~km}^{2}$ in the period 1922-1987 because of the growing demand for drinking water for the city. Now water is extracted from three rivers (Pirita, Jägala, and Soodla) by means of a complex network of major reservoirs and canals covering approximately $4.5 \%$ of the Estonian territory. On the basis of a normal water level of $190 \mathrm{~cm}$ (36.62 $\mathrm{m}$ above sea level according to the Baltic system), the area of Lake Ülemiste is $9.75 \mathrm{~km}^{2}$ and the corresponding usable storage is $0.016 \mathrm{~km}^{3}$. Since the beginning of the 1990s, with the collapse of the Soviet Union and reestablishment of the Republic of Estonia in 1991, the 4-fold decline in water consumption led to a decrease in the inflow to the lake and also to a decline in the nutrient concentration of the water. The long-term trends of annual means of $\mathrm{NO}_{3}$ and $\mathrm{PO}_{4}$ ions show a rapid decline: the annual means of these ions were respectively 2.6 and $0.01 \mathrm{mg} / \mathrm{L}$ for the period 1992-2004 but twice as high for 1971-1991. Monthly means of Tot-N and Tot-P during the last four years ranged as follows: $0.96-3.153 \mathrm{mg} \mathrm{N} / \mathrm{L}$ and $0.014-0.083 \mathrm{mg} \mathrm{P} / \mathrm{L}$. Lake Ülemiste is a typical Estonian calcium-bicarbonate waterbody. Both $\mathrm{Ca}$ and $\mathrm{HCO}$ ions undergo seasonal dynamics repeated from year to year and showing a declining trend in the mean annual concentrations as well as in annual amplitudes since the catchwater influence decreased in 1990. At present, the annual means of these parameters are $72.8 \mathrm{mg} / \mathrm{L}$ for calcium and $173 \mathrm{mg} / \mathrm{L}$ for bicarbonate. The lake water is alkaline ( $\mathrm{pH} 7.2-8.9)$ with a large buffering capacity. The lake tends to stratify in early spring under the ice cover but never for very long. The period of ice cover lasts 141 days (averaged over the last 43 years).

Table 1. Morphometrical and hydrological characteristics of Lake Ülemiste in 1904, 1965, 1975, 2000 , and 2004

\begin{tabular}{l|c|c|c|c|c}
\hline \multicolumn{1}{c|}{$\begin{array}{c}\text { Year of investigation } \\
\text { of macrophytes }\end{array}$} & 1904 & 1965 & 1975 & 2000 & 2004 \\
\hline Mean area, $\mathrm{km}^{2}$ & & 9.62 & 9.34 & 9.79 & 9.90 \\
Mean depth, cm & 110 & 320 & 271 & 340 & 348 \\
Mean volume, km ${ }^{3}$ & n.d. & 0.0308 & 0.0253 & 0.0333 & 0.0345 \\
Residence time, years & n.d. & 1 & 0.47 & 1.07 & 1.12 \\
Secchi depth, m & n.d. & n.d. & 0.5 & $0.3-0.5$ & $0.65-0.7$ \\
Vegetation period, days & n.d. & 219 & 236 & 263 & 220 \\
Water level during the & n.d. & n.d. & 65 & 185 & 218 \\
$\quad$ macrophyte investigation & & & & & \\
$\quad$ (cm above the zero & & & & & \\
baseline 34.72 m) & & & & &
\end{tabular}

n.d. - No data. 


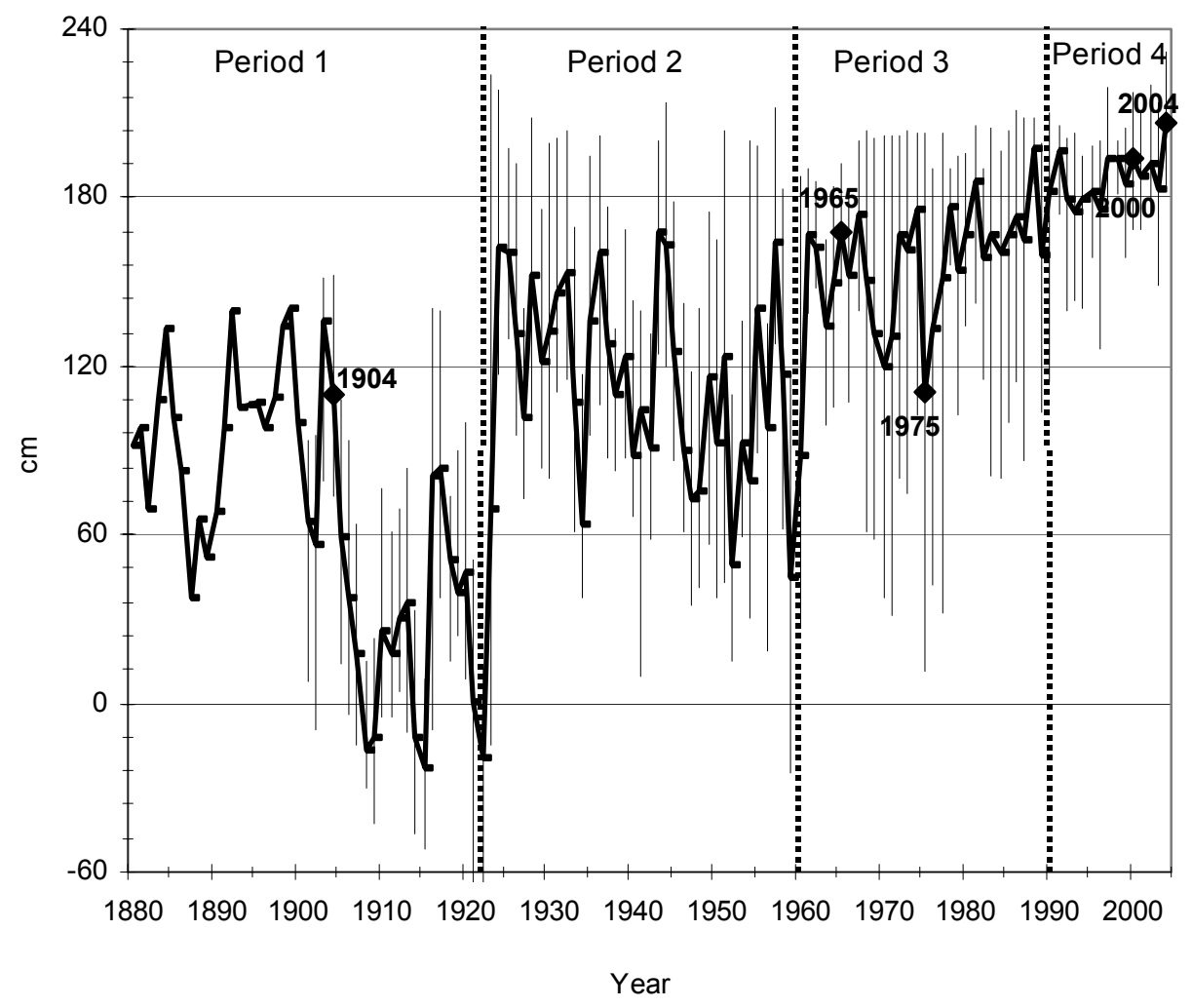

Fig. 2. Long-term fluctuations of the mean water level ( $\mathrm{cm}$ above the zero baseline $34.72 \mathrm{~m}$ ) in Lake Ülemiste from 1880. Vertical lines mark the upper and lower limits of the annual water level. The numbers denote the years of the investigation of macrophytes.

The lake has a gently sloped littoral zone. The depth zones of $0-2 \mathrm{~m}, 2-3 \mathrm{~m}$, 3-4 $\mathrm{m}$, and $\geq 4 \mathrm{~m}$ represent $12 \%, 19 \%, 58 \%$, and $11 \%$ of the total, respectively. The shoreline is regular, with a few sheltered bays and floodplains. There are man-made shorelines in the north, north-east, and southern parts of the lake. The bottom of the lake is mainly covered with soft sediments (mud) as well as sand and gravel. The main morphometrical and hydrological characteristics of Lake Ülemiste in the years 1904, 1965, 1975, 2000, and 2004 are given in Table 1.

\section{HISTORICAL SURVEY OF THE RESEARCH OF MACROFLORA IN LAKE ÜLEMISTE}

The first information about the macroflora of Lake Ülemiste can be found in the bulky treatise of the flora of the surroundings of Tallinn (at that time called Reval) by Russow (1862). This research shows that by that time the SE shore of the lake had already been colonized by wide stands of Scolochloa festucacea, 
Phragmites australis, and Schoenoplectus lacustris, extending in places to onefourth verst $(1$ verst $=1.067 \mathrm{~km})$ offshore. Russow also described the abundant vegetation at the inflow of the Kurna Stream and the swampy area surrounding the stream. Regrettably, these data cannot be used for exact comparison with our data because the extent of the area of his investigation is not clear. Many species found in the area by Russow can be seen there today as well. It is interesting to note that Nymphaea alba, mentioned by Russow, also grew there in 2000 but had not been found by the three investigators in the intervening period.

The first proper study of Lake Ülemiste was published by Schneider (1908). Comparing his results with Russow's study, Schneider established that in the interim (a period of 40 years) the distribution area of reed had extended to $1 \mathrm{~km}$ offshore, and pines had grown over the sand dunes near the lake. Schneider considered emergent monocotyledonous angiosperms (helophytes) as dominants in the lake, as is the case also today. The main characteristic community-forming species was Scolochloa festucacea. It formed a thick belt at a depth of $0.25-1.5 \mathrm{~m}$. The area in the shallower water bordering the water's edge was inhabited by sedges and the deeper area (at a depth of 1.5-2.5 m) was occupied by a belt of Phragmites australis. The above-mentioned three zones did not surround the lake as three closed concentric circles but occurred as fragmentary reaches of different width and length. The reaches consisted either of all the above-named species or of only one or two of them, while bands of different species were not distinctly separated from each other. In the south-western part of the lake the width of the zones of $S$. festucacea and $P$. australis was about $1 \mathrm{~km}$. Schneider estimated that the proportion of $S$. festucacea was much larger than that of $P$. australis. Submerged species of Potamogeton (mainly $P$. gramineus and $P$. perfoliatus) occurred in deeper areas or grew near the shore in places without emergents. Schneider recorded a total of 16 taxa of vascular plants and 3 species of macroalgae. Cladophora glomerata formed dense mats in shallow inshore habitats. Floating assemblages of Spirogyra occurred in the mouths of ditches issuing into the eastern part of the lake; Zygnema accompanied both Cladophora and Spirogyra. In addition, Schneider published a complete list of the species found by Russow in the surroundings of the lake.

Schneider's floristic list chiefly comprised species with a wide ecological range and species preferring habitats with high trophy levels. The presence of dense mats of green algae, and particularly the intensive propagation of phytoplankton in the last decade of the 19th century (the heaviest bloom took place in 1896), led to the conclusion that Lake Ülemiste was already eutrophic at the turn of the century. In his investigation Schneider mentioned two main factors endangering water quality: frequent algal blooms and large amounts of mud.

Sixty years later, the zone of macrophytes had narrowed, the width of the zone being now 30-50 m and the depth mainly 1.5-1.6 $\mathrm{m}$ (Pork, 1968). The two dominating species, $S$. festucacea and $P$. australis, had changed places: $P$. australis had become predominant and the area of $S$. festucacea had diminished. In 1965, the proportions of S. festucacea and of Schoenoplectus lacustris were nearly equal. The distribution area of $P$. australis had meanwhile apparently expanded. Schneider had found this species only in two localities: in the western part of the 
lake and in the estuary of the Kurna Stream. According to the estimation by Pork (1968), sedges were quite abundant. Floating-leaved plants were represented mainly by Polygonum amphibium growing at the edge of the zone of emergents or within it where emergents were sparse. In 1904, this species formed large dense patches (diam. up to $100 \mathrm{~m}$ ) near the south-eastern shore, occurring less copiously in the lake's south-western part as well. Potamogeton lucens dominated among submerged angiosperms, followed by P. perfoliatus in 1968. Sparse stands of $P$. lucens extended to a distance of $400 \mathrm{~m}$ from the shore to a depth of $2.5 \mathrm{~m}$. The area covered by this species had clearly expanded; Schneider (1908) had recorded it only at one site - in the estuary of the Kurna Stream.

Ten years later Mäemets (1979) reported a decrease in the width of the zone of macrophytes as well as in the whole area covered by vegetation. The predominant species was Phragmites australis as before. With respect to abundance, Scolochloa festucacea was surpassed by Schoenoplectus lacustris, which bordered the belt of $P$. australis, mixing with it in places or occurring as individual patches within the belt. Here and there single pure stands of $S$. lacustris were found at a considerable distance from the lake. The share of $S$. festucacea was smaller, but it occurred quite frequently along the shores, forming individual stands or growing with other species. The submerged vegetation was less developed and more unevenly distributed. The role of floating-leaved plants was still less significant, and Polygonum amphibium was the predominating species. As before, Potamogeton lucens dominated among submerged plants. The share of sedges had diminished.

\section{MATERIAL AND METHODS}

The material for the present research was collected by the authors from Lake Ülemiste on 24-27 July 2000. We studied macrophytes in 232 sites using a motorboat and investigated the entire shoreline of the lake. The sites were determined by the uniformity of the vegetation; as this changed, a new site was designated. At every site we recorded the dominant species and the list of other taxa, calculated the total coverage of vegetation, and measured the depth limits of the sites. The mean GPS (Geographical Position of Sites) was used for the exact fixing of sites. The digital map by the Estonian Map Centre, based on flight data in 1994 and 1995, and the MapInfo program were used for calculating the distances from the shoreline and the surface covered by macrovegetation. At the end of August 2004, total coverage of macrophytes, their maximum zone width, and maximum colonization depth were determined by Pedusaar for comparison with the data from 2000.

The water levels of the lake were obtained from the permanent graduated staff gauge readings. The euphotic layer $\left(Z_{1 \%}\right)$ was calculated by the formula:

$$
Z_{1 \%}=\frac{4.6}{K_{\mathrm{d}, \mathrm{PAR}}}
$$

where $K_{\mathrm{d} \text { PAR }}$ is averaged over depth diffuse attenuation coefficient. 
The guides by Mäemets (1984) and Leht (1999) were used for the identification of vascular plants, and the plant names are given according to these authors. The algae were distinguished using the guide by Vinogradova et al. (1980).

\section{RESULTS AND DISCUSSION Flora and vegetation of Lake Ülemiste in 2000}

In 2000 , the macrophyte vegetation covered $5.4 \%$ of the lake (Fig. 1). In 2004, the coverage was $6 \%$. In 2000 , the mean width of the zone of macrophytes was $48.4 \mathrm{~m}$ and the mean depth $1.4 \mathrm{~m}$. The area covered with vegetation was more extensive in the south-western, southern, and south-eastern parts of the lake and the belt was the widest $(286 \mathrm{~m})$ in the south-west (Fig. 1). Phragmites australis reached the maximum depth $(2.5 \mathrm{~m})$ in the western and Potamogeton lucens in the northern part. As the shores are largely even, gently sloping, or shallow and flat, and not heavily indented, the flora and vegetation have quite similar features in most of the lake. Two communities $-P$. australis-S. lacustris-P. amphibium and $P$. australis $-S$. lacustris - covered $68 \%$ of the vegetation. The list of the macrophytes found over the entire lake contains 41 species of vascular plants, 1 moss species, and 5 species of macroalgae.

We can differentiate a typical and a non-typical part of Lake Ülemiste. The latter made up only a small portion of the whole surface of the lake $(0.9 \%)$ having some different ecological conditions and a different floristic composition with a high species diversity (Fig. 1).

\section{Typical part of the lake}

The flora of the typical part of Lake Ülemiste contained only 9 species of macrophytes, 3 of them are emergent, 1 floating-leaved, and 5 submerged (Table 2). Species characteristic of the typical part of the lake were found also at non-typical sites, but not vice versa. The species in Table 2 are arranged according to their frequency.

Table 2. List of macrophytes in the typical part of Lake Ülemiste in 2000

\begin{tabular}{l|c|c|c}
\hline \multicolumn{1}{c|}{ Species } & $\begin{array}{c}\text { Number of } \\
\text { findings }\end{array}$ & $\begin{array}{c}\text { Frequency, } \\
\%\end{array}$ & $\begin{array}{c}\text { Depth limits, } \\
\mathrm{m}\end{array}$ \\
\hline Phragmites australis & 133 & 57.3 & $0.2-2.5$ \\
Schoenoplectus lacustris & 97 & 41.8 & $0.2-1.9$ \\
Polygonum amphibium & 62 & 26.7 & $0.3-2.0$ \\
Scolochloa festucacea & 36 & 15.5 & $0.2-2.0$ \\
Potamogeton lucens & 35 & 15.1 & $0.5-2.5$ \\
P. perfoliatus & 25 & 10.8 & $0.7-1.3$ \\
P. pectinatus & 8 & 3.4 & $0.5-1.5$ \\
P. gramineus & 7 & 3.0 & $0.4-1.4$ \\
P. filiformis & 6 & 2.6 & $0.1-0.7$
\end{tabular}


Phragmites australis was the predominant species with the highest frequency along most of the shoreline at a depth of $0.2-2.5 \mathrm{~m}$ (mainly $1-1.5 \mathrm{~m}$ ). The width of the reed-belt varied from a few metres to some hundred metres. The belt of Phragmites was situated mostly near the shoreline, sometimes separate stands occurred farther offshore. The reed belt was somewhat fragmentary on the northwestern shore and was absent along an extensive stretch of the northern shore. The reason is probably the recently finished renovation work on this shoreline. Reeds were usually $2.5-3 \mathrm{~m}$ tall, exceeding in places $4 \mathrm{~m}$ ( $\max 4.2 \mathrm{~m})$. Dense (coverage over $70 \%$ ) and tall stands of $P$. australis with panicles occurred quite often; in their vicinity (obviously in similar conditions) we encountered other stands, much lower, sparser and without panicles. Neuhaus et al. (1993) described different genotypes of Phragmites australis within a lake.

Schoenoplectus lacustris was the second most frequent and abundant among the dominant species. It bordered the lakeward zone of $P$. australis, forming a more or less pure belt near the shoreline and single scattered stands farther offshore or mixed communities with other emergents or with floating-leaved Polygonum amphibium. S. lacustris was found along most of the shoreline, but was absent from some sites of the western shore and in the area without emergents in the northern part. The coverage of $S$. lacustris communities varied from $20 \%$ to $80 \%$, with a common depth limit of $1-1.5 \mathrm{~m}$ and a maximum of $1.9 \mathrm{~m}$; the plants were usually about $2 \mathrm{~m}$, sometimes $2.5-2.7 \mathrm{~m}$ tall.

Polygonum amphibium is the third dominant species, which occurred frequently and abundantly on all shore stretches, bordering with emergents or growing among them. This species was not recorded on a rather long stretch of the western shore and on the northern part of the lake, which partly coincided with the area without S. lacustris. P. amphibium occurred as pure monospecific patches (some tens of metres in diameter) or formed large fields (several hundreds of metres in diameter). Its coverage on these patches and fields was often $40 \%$ to $70 \%$, sometimes even $100 \%$. Elsewhere it was found sporadically among other species, or it formed mixed communities with helophytes or with some Potamogeton species.

Scolochloa festucacea grew as separate stands bordered by P. australis or $S$. lacustris, or sometimes forming mixed communities with them. At some sites $S$. festucacea was the only emergent; patches of $P$. amphibium or some Potamogeton species occurred farther offshore. Most of the habitats were situated in the north-eastern part of the lake. The species was absent from extensive areas of the south-western and south-eastern shores.

The five Potamogeton species were concentrated mainly in the northern part of the lake, P. lucens being the most widely distributed of them. It occurred as small patches and sporadically in the whole lake; larger stands were distributed mainly in the northern part. Some plants had characteristic leaves with spine-like apices (length 1-1.5 cm), belonging to f. acuminatus. P. perfoliatus was scattered; small stands grew mainly in the northern part of the lake, often with other 
pondweeds. P. pectinatus was not found earlier in Lake Ülemiste. It formed smaller patches in the northern and north-eastern parts of the lake. P. gramineus occurred without or with poorly developed floating leaves. Further, we also found the hybrid $P$. gramineus $\times P$. lucens occurring at 7 sites. It was found also by Schneider (1908) and Mäemets (1979). The latter identified also the hybrid $P$. gramineus $\times P$. perfoliatus from the lake. $P$. filiformis occurred only as f. fasciculatus; the plants were less than $10 \mathrm{~cm}$ tall.

\section{Non-typical part of the lake}

The non-typical part of the lake includes several small areas in different parts of the lake (Fig. 1). The flora of this part of the lake is listed in Table 3. Helophytes, including some shore plants and plants characteristic of swamps, contain 22 species in Lake Ülemiste. Among them Sparganium erectum s.str., forming a community in a small round inlet in the north-western part of the lake $(\mathrm{NW})^{*}$, is worth mentioning. The species is considered very rare in Estonia. In addition, we recorded 5 species of submerged plants and 5 species of floating and floating-leaved plants growing among the vascular plants.

The specific vegetation in some shallow areas of the non-typical part of the lake, close to the northern and eastern shores, is worthy of a more detailed description. On the sandy bottom small-sized specimens of Potamogeton filiformis, P. gramineus, Agrostis stolonifera var. prorepens, Eleocharis acicularis, and E. palustris could be found. A few specimens of Chara (presumably C. contraria) were found at three sites. Stones were densely covered with jelly-like light green colonies of Ophrydium versatile (Ciliata) similar to the colonies of some Cyanophyceae species, accompanied sometimes by a few plants of small-sized Fontinalis antipyretica. At one site, ball-shaped colonies of the green alga Cladophora aegagropila were found between stones. Patches of the abovedescribed vegetation formed areas of only a few or some tens of metres in diameter.

In addition to vascular plants, the following mosses and algae occurred in the non-typical parts of Lake Ülemiste:

Fontinalis antipyretica Hedw. was found at two sites near the northern shore $(\mathrm{N})$, growing in small numbers with green algae on stones in shallow water.

Cladophora aegagropila (L.) Rabenh. was encountered once in the northern part of the lake $(\mathrm{N})$ at a depth of $0.7 \mathrm{~m}$ on the bottom between stones. At another site, an algal ball was floating on the water surface among emergents near the eastern shore (OO).

Cladophora glomerata (L.) Kütz. was growing on stones at two sites near the mouth of the Pirita-Ülemiste Canal (P) in shallow water.

Spirogyra spp. occurred at two sites together with the previous species. The third site was located a little westward of them.

* Abbreviations in brackets used in Fig. 1 and in Table 3. 
Table 3. List of vascular plants in the non-typical part of Lake Ülemiste. Explanations for the locations are given as acronyms in the legend to Fig. 1; comm. - the species forms communities. Nomenclature according to Leht (1999)

\begin{tabular}{c|c|c|c|c}
\hline Species & $\begin{array}{c}\text { Number and sites of findings } \\
\text { in } 2000\end{array}$ & $\begin{array}{c}\text { Schneider, } \\
1908\end{array}$ & $\begin{array}{c}\text { Pork, } \\
1968\end{array}$ & $\begin{array}{c}\text { Mäemets, } \\
1979\end{array}$ \\
\hline
\end{tabular}

\section{Emergent/Helophytic incl. some plants of shores and swamps}

\begin{tabular}{|c|c|}
\hline Equisetum fluviatile & $5(\mathrm{NO}, \mathrm{UK})$ \\
\hline Rumex aquaticus & $1(\mathrm{~K})$ \\
\hline Ranunculus lingua & $2(\mathrm{~K}, \mathrm{UK})$ \\
\hline Sium latifolium & $1(\mathrm{~K})$ \\
\hline Cicuta virosa & $1(\mathrm{~K})$ \\
\hline Lysimachia thyrsiflora & $1(\mathrm{NW})$ \\
\hline Lysimachia vulgaris & 2 (WP) \\
\hline Menyanthes trifoliata & $2(\mathrm{NO}, \mathrm{UK})$ comm. \\
\hline Stachys palustris & $2(\mathrm{~N}, \mathrm{NO})$ \\
\hline Alisma plantago-aquatica & $2(\mathrm{NW}, \mathrm{N})$ \\
\hline Butomus umbellatus & $8(\mathrm{NW}, \mathrm{N}, \mathrm{NO}, \mathrm{UK}$ \\
\hline Iris pseudacorus & $2(\mathrm{~W}, \mathrm{NO})$ \\
\hline Phalaris arundinacea & $1(\mathrm{~N})$ joint comm. \\
\hline $\begin{array}{l}\text { Agrostis stolonifera } \\
\text { [var. prorepens] }\end{array}$ & $4(\mathrm{~N}, \mathrm{O})$ \\
\hline Sparganium erectum s.l. & $3(\mathrm{P}, \mathrm{K}, \mathrm{UK})$ \\
\hline Sparganium erectum s.str. & $1(\mathrm{NW})$ \\
\hline Sparganium spp. & 15 (P, NW, NO, UH \\
\hline Typha angustifolia & $\begin{array}{r}3(\mathrm{~K}, \mathrm{UK}, \mathrm{SW}) \mathrm{sep} \\
\text { and joint comm }\end{array}$ \\
\hline Typha latifolia & $\begin{array}{l}13(\mathrm{NW}, \mathrm{P}, \mathrm{NO}, \mathrm{W} \\
\text { in some of then }\end{array}$ \\
\hline Eleocharis acicularis & $2(\mathrm{~N}, \mathrm{O})$ \\
\hline Eleocharis palustris & $1(\mathrm{~N})$ \\
\hline Carex spp. & $7(\mathrm{NW}, \mathrm{NO}, \mathrm{W}, \mathrm{SO}$ \\
\hline \multicolumn{2}{|l|}{ Submersed plants } \\
\hline Ceratophyllum demersum & $1(\mathrm{~K})$ large comm. \\
\hline Hippuris vulgaris & $2(\mathrm{NW}, \mathrm{P})$ \\
\hline Mentha aquatica & $1(\mathrm{~N})$ \\
\hline Utricularia vulgaris & $1(\mathrm{NW})$ \\
\hline Stratiotes aloides & $1(\mathrm{~K})$ comm. \\
\hline
\end{tabular}

\section{Floating and floating-leaved plants}

$\begin{array}{ll}\text { Nymphaea alba } & 1(\mathrm{~K}) \text { Russow, 1862** } \\ \text { Nuphar lutea } & 7(\mathrm{P}, \mathrm{NO}, \mathrm{K}) \\ \text { Hydrocharis morsus-ranae } & 1(\mathrm{~K}) \\ \text { Potamogeton natans } & 1(\mathrm{~K}) \text { comm. } \\ \text { Lemna minor } & 1(\mathrm{~K})\end{array}$

* var. prorepens Koch according to Viljasoo (1979).

** Before the year 2000 Nymphaea alba was found only by Russow (1862). 
Mougeotia spp. was found in one location close to the mouth of the PiritaÜlemiste Canal, together with C. glomerata and Spirogyra. A few small individuals of Chara spp. (presumably C. contraria) were growing at three shallow sites near the eastern shore (OO) on the sandy bottom with Potamogeton filiformis, P. gramineus, etc.

\section{CHANGES IN THE MACROFLORA AND VEGETATION DURING THE 20TH CENTURY}

Comparison of our results with previous ones reveals that the total coverage of macrovegetation and the maximum width of the macrophyte zone have decreased in the course of 100 years. Also the relative importance of submerged macrophytes has decreased (Table 4). Transition from the submerged to emerged vegetation is part of the natural process of lake succession, which has most accelerated in small shallow productive lakes (Duarte et al., 1986).

The floristical composition in the typical part of the lake has not changed in the course of 100 years (Table 4), but the relationships between the species have changed. Scolochloa festucacea, the main dominant in the lake in 1904, comes

Table 4. Changes in the flora and vegetation of Lake Ülemiste. Year of fieldwork is given in parentheses

\begin{tabular}{|c|c|c|c|c|c|}
\hline & $\begin{array}{l}\text { Schneider, } \\
1908(1904)\end{array}$ & $\begin{array}{c}\text { Pork, } \\
1968(1965)\end{array}$ & $\begin{array}{l}\text { Mäemets, } \\
1979(1975)\end{array}$ & $\begin{array}{l}\text { Trei \& Pedusaar } \\
(2000)\end{array}$ & $\begin{array}{l}\text { Pedusaar } \\
\text { (2004) }\end{array}$ \\
\hline $\begin{array}{l}\text { Number of species } \\
\text { of vascular plants }\end{array}$ & 16 & 28 & 26 & 40 & \\
\hline $\begin{array}{l}\text { Number of taxa of } \\
\text { algae }\end{array}$ & 3 & No data & No data & 5 & \\
\hline $\begin{array}{l}\text { Total cover of } \\
\text { macrophytes }\end{array}$ & No data & ca $10 \%$ & Less than $10 \%$ & $5.4 \%$ & $6 \%$ \\
\hline $\begin{array}{l}\text { Maximum width } \\
\text { of the macrophyte } \\
\text { zone, } \mathrm{m}\end{array}$ & 1000 & 500 & 400 & 286 & 276 \\
\hline $\begin{array}{l}\text { Maximum } \\
\text { colonization depth } \\
\text { of macrophytes, } m\end{array}$ & No data & 3.9 & 2.5 & 2.5 & 2.9 \\
\hline $\begin{array}{l}\text { Dominating species } \\
\text { in the order of } \\
\text { abundance }\end{array}$ & $\begin{array}{l}\text { 1. S. festucacea } \\
\text { 2.P. australis } \\
\text { 3. Carex } \\
\text { 4.P. gramineus } \\
\text { 5.P. perfoliatus } \\
\text { 6.P. amphibium }\end{array}$ & $\begin{array}{l}\text { 1.P. australis } \\
\text { 2.3. S. festucacea } \\
\text { 2. 3. S. lacustris } \\
\text { 4. Carex } \\
\text { 5.P. amphibium } \\
\text { 6. P. lucens }\end{array}$ & $\begin{array}{l}\text { 1. P. australis } \\
\text { 2. S. lacustris } \\
\text { 3. S. festucacea } \\
\text { 4. P. lucens } \\
\text { 5.P. amphibium }\end{array}$ & $\begin{array}{l}\text { 1.P. australis } \\
\text { 2. S. lacustris } \\
\text { 3.P. amphibium } \\
\text { 4. S. festucacea } \\
\text { 5.P. lucens } \\
\text { 6. P. perfoliatus }\end{array}$ & \\
\hline
\end{tabular}

Note: As to the order of the dominating species, the three first species are given according to the arrangement suggested by the authors of the respective studies. For better comparison, we attempted to arrange also the next $2-3$ species using their data. 
only fourth today. Phragmites australis has become the primary dominant in the lake, Schoenoplectus lacustris has also steadily expanded its area of distribution to take the second place in the lake. Sedges have lost their importance, apparently because of the stabilization of the water level in recent years. These days Polygonum amphibium is the third most important dominant. Unfortunately, it is quite difficult to ascertain the relationship between Polygonum amphibium and Potamogeton lucens in 1965 (Pork, 1968) and in 1975 (Mäemets, 1979) because both species had a modest position. It is clear that Potamogeton lucens has increased since 1904 (Schneider, 1908), when it was found in only one place. However, nowadays it is less frequent than in 1975. The decrease in the frequency of P. lucens was noticed also in Lake Peipsi in 1970-1980 (Mäemets \& Mäemets, 2001).

The list of species of the non-typical part of the lake (Table 3) contains ten species of angiosperms, one moss species, and three taxa of algae that are new to Lake Ülemiste. At the same time 14 previously recorded taxa of angiosperms were not found in 2000. As these taxa were found only in a few localities and in small numbers, we cannot draw any particular conclusions about their absence. It is even possible that we overlooked some of them. As to the new species, Ceratophyllum demersum is worthy of attention. In 2000, it formed a large (about $11000 \mathrm{~m}^{2}$ ) and very dense field (coverage 95-100\%) at a depth of $0.7-0.8 \mathrm{~m}$ in the estuary of the Kurna Stream. Plants filled the whole water column from the surface to the bottom. This shows a surplus of nutrients in the inflowing waters. We can also identify some changes in the distribution of a few other species in the lake. For instance, Potamogeton natans was found in 1975, not abundantly, mainly in the area of the south-western and northern shores (Mäemets, 1979). We found it forming communities in only one site, in the estuary of the Kurna Stream. In 1965 Phalaris arundinacea was forming communities in the southwestern, southern, and south-eastern parts of the lake (Pork, 1968); in 1975 it was not found (Mäemets, 1979); in 2000 it was recorded in one site near the southern shore. The share of Typha latifolia has increased since 1975; Mäemets (1979) found it at only one site in a small bay on the north-western shore.

\section{ENVIRONMENTAL FACTORS THAT COULD AFFECT MACROPHYTES IN LAKE ÜLEMISTE}

In contrast to phytoplankton or bacterioplankton, macrophytes react slowly but progressively to changes in the aquatic environment. Therefore macrophytes should function as integrators of environmental conditions to which they are subjected and thus can be used as long-term indicators (Melzer, 1999). One hundred years is a long period of time, and both natural succession due to lake ageing and intensive human interference have produced complex changes in Lake Ülemiste. Consequences of the eutrophication of lakes for macrophytes have been amply described (Suominen, 1968; Morgan, 1970; Jupp \& Spence, 1977; Hough et al., 1989), and a theory of alternative stable states was developed and 
summarized (Scheffer, 1998) and revised (Dokulil \& Teubner, 2003). One can find numerous studies about factors that can affect plant growth in a waterbody (Hutchinson, 1975; Chambers \& Kalff, 1985; Duarte et al., 1986; Duarte \& Kalff, 1987, 1988; Gasith \& Hoyer, 1998; Coops et al., 2003). We have limited our discussion mainly to water-level changes and underwater light conditions.

Water-level fluctuations have had an overriding effect on the management of Lake Ülemiste as the lake's prime function is to serve as a raw water source for the supply of water to the city of Tallinn. The long-term water-level fluctuations in Lake Ülemiste are shown in Fig. 2. We can contrast four very different periods. During the first period, the lake had no artificial inflow, only a natural catchment area $\left(79 \mathrm{~km}^{2}\right)$. The second period started with the excavation of the Pirita-Ülemiste Canal in 1922. The ever-increasing demand for water of the city since the beginning of the 1960s caused an enlargement of the catchment area and a high external water load in the third period. Since the beginning of the 1990s, after the collapse of the Soviet Union, the city's demand for water decreased, and the fourth period started. Eight dry periods were recorded during the 20th century. Dry years caused especially pronounced drawdowns in the water level during the first period. Lower water levels, and therefore a smaller mean depth of the lake, could explain the greater maximum distance of macrophytes from the shore in 1904, and could also be the reason for the dominance of Scolochloa festucacea (Table 4). The annual range of the fluctuations was high (maximum $2.39 \mathrm{~m}$ in 1923) despite the intensively regulated water level in the second and third periods (Fig. 2). There are no macrophyte investigations in the second period, but the high fluctuating water level at this time clearly contributed to the loss of the habitats of macrophytes in the lake. A number of studies have suggested that water-level fluctuations may be a catastrophic disturbance for submerged plant communities (Coops et al., 2003), and that water-level manipulations lead to the expansion of emergent vegetation (Ter Heerdt \& Drost, 1994). In fact, the changes in the species composition as well as the reduced macrophyte coverage had already taken place by the beginning of the third period (Fig. 2 and Tables 1 and 4). To summarize, the widely fluctuating water level as well as the steadily increasing mean annual water level since the beginning of the 1960s favoured a decline of the macrophyte community by the end of the 20th century.

Time-series plots of the mean water level and euphotic depth for the vegetation period since the beginning of the 1970s demonstrate a clear trend in Lake Ülemiste: a linear upward trend in the mean water level already mentioned in the first section, and a polynomial trend with a tendency for increasing euphotic depth (Fig. 3). Duarte et al. (1986) stated that long-term changes in underwater irradiance should lead to parallel changes in submerged cover and biomass at any one site. Light limitation is generally considered the main reason why submerged macrophyte vegetation is poorly developed in turbid lakes. In our case, an improvement in underwater light conditions and an increase in the mean water level coincided in time. The euphotic depth increased by ca $0.4 \mathrm{~m}$ but at the same time the water 


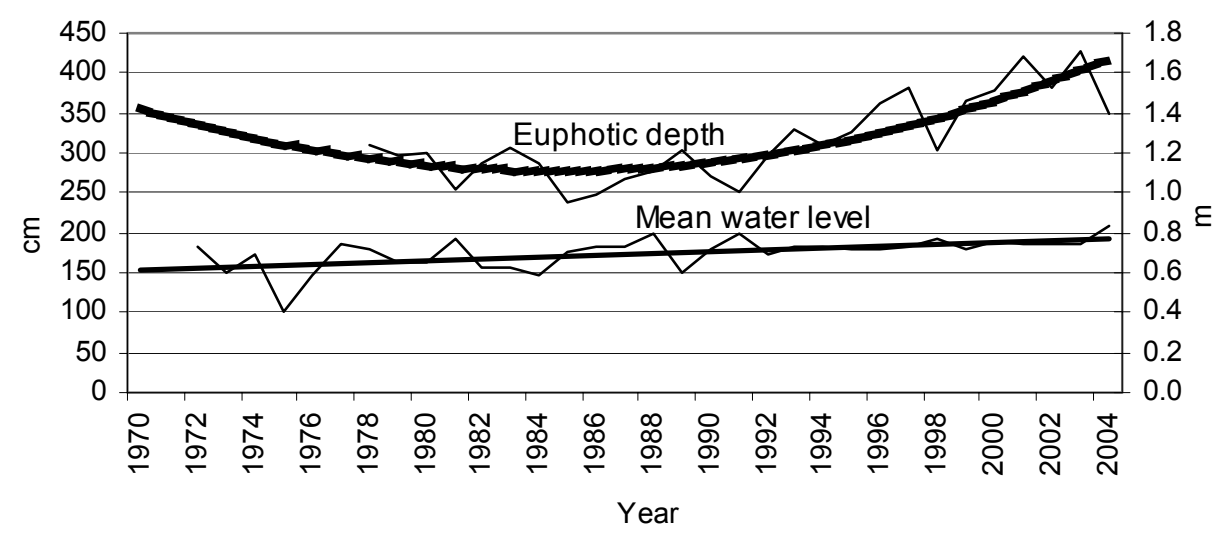

Fig. 3. Time-series plots of the mean water level ( $\mathrm{cm}$ above the zero baseline $34.72 \mathrm{~m}$ ) and euphotic depth (m) for the vegetation period in Lake Ülemiste in 1970-2004.

level increased by ca $0.3 \mathrm{~m}$. So, for the submerged macrophytes, no pronounced improvement in the light conditions took place and this can explain why they did not recover.

Other factors, of course, could have restricted the macrophyte community in the course of the last 100 years. Soft sediments have been already mentioned by previous investigators (Schneider, 1908; Mäemets, 1979). A thick layer of $\mathrm{CaHCO}_{3}$ on the leaves of submerged macrophytes, especially on Potamogeton, as well as the numerous renovations on the shorelines could suppress the growth. Fish may, directly or indirectly, affect vegetation (Jeppesen et al., 1998). Bream (Abramis brama), a notorious benthivore, has predominated in Lake Ülemiste since the beginning of the 20th century (Schneider, 1908) and has been recorded as a dominant in respect of abundance and biomass up to the present (Kangur, 1998). None of the above-mentioned environmental factors is mutually exclusive, and we believe each has played an essential role and will do so in the future in the development of the macrophyte community in Lake Ülemiste.

According to the literature and practice associated with the restoration of lakes at the end of the 20th century and the beginning of the 21 st century, submerged macrophytes are a very important structural element in lakes and may markedly affect the environmental conditions of a lake by their ability to stabilize the clearwater state (Jeppesen et al., 1998). Lake Ülemiste is a shallow lake with the potential for more extensive macrophyte cover. If the underwater conditions continue to improve, or at least stabilize along with water-level fluctuations, some macrophyte recovery can be expected in the near future. New large canopies of Potamogeton lucens f. acuminatus were recorded in the southern and northern parts of the lake in 2004. Also, during 2004, the annual water level was the highest known for the lake history, but the macrophyte coverage, the maximum width and depth of their zone, were not much lower than in 2000. 


\section{CONCLUSIONS}

Although studies of macrophytes in Lake Ülemiste were scarce and sporadic during the 20th century, the following general conclusions can be drawn:

- The area covered by macrophytes and the width of the zone of macrophytes have decreased in the course of 100 years.

- The floristic composition in the typical part of the lake has not changed, but the relationships between the dominating species have changed. In 2000, Phragmites australis was the primary dominant whereas Scolochloa festucacea dominated at the beginning of the 20th century. The latter gradually lost its dominant status over the century.

- Several changes in the floristic composition and distribution of species have taken place in the non-typical part of the lake. The most significant is the appearance of Ceratophyllum demersum, which has formed a large community $\left(11000 \mathrm{~m}^{2}\right)$ in the estuary of the Kurna Stream.

- Widely fluctuating water level as well as the steadily increasing mean annual water level since the beginning of the 1960s favoured a decline in the macrophyte community by the end of the 20th century. The improvement in underwater conditions coincided with the rising mean water level at the end of the 20th century and so did not lead to the recovery of submerged plants.

\section{ACKNOWLEDGEMENTS}

We are grateful to the senior management of Tallinn Water Ltd., and to Ester Jaigma and Penny Mountain who kindly edited the English. The manuscript profited from the criticism and useful comments and recommendations by the anonymous reviewer.

\section{REFERENCES}

Chambers, P. A. \& Kalff, J. 1985. Depth distribution and biomass of submerged aquatic macrophyte communities in relation to Secchi depth. Can. J. Fish. Aquat. Sci., 42, 701-709.

Coops, H., Beklioglu, M. \& Crisman, T. L. 2003. The role of water-level fluctuations in shallow lake ecosystems - workshop conclusions. Hydrobiologia, 506-509, $23-27$.

Dokulil, M. T. \& Teubner, K. 2003. Eutrophication and restoration of shallow lakes - the concept of stable equilibria revisited. Hydrobiologia, 506-509, 29-35.

Duarte, C. M. \& Kalff, J. 1987. Latitudinal influences on the depths of maximum colonization and maximum biomass of submerged angiosperms in lakes. Can. J. Fish. Aquat. Sci., 44, 1759 1764.

Duarte, C. M. \& Kalff, J. 1988. Influence of lake morphometry on the response of submerged macrophytes to sediment fertilization. Can. J. Fish. Aquat. Sci., 45, 216-221.

Duarte, C. M., Kalff, J. \& Peters, R. H. 1986. Patterns in biomass and cover of aquatic macrophytes in lakes. Can. J. Fish. Aquat. Sci., 43, 1900-1908.

Gasith, A. \& Hoyer, M. V. 1998. Changing influence along lake size and depth gradients. In The Structuring Role of Submerged Macrophytes in Lakes (Jeppesen, E., Søndergaard, M., Søndergaard, M. \& Christoffersen, K., eds), pp. 381-392. Springer-Verlag, New York. 
Hough, R. A., Fornwall, M. D., Negele, B. J., Thompson, R. L. \& Putt, D. A. 1989. Plant community dynamics in a chain of lakes: principal factors in the decline of rooted macrophytes with eutrophication. Hydrobiologia, 173, 199-217.

Hutchinson, G. H. 1975. A Treatise on Limnology. Vol. 3. Limnological Botany. Wiley, New York.

Jeppesen, E., Søndergaard, M., Søndergaard, M. \& Christoffersen, K. (eds) 1998. The Structuring Role of Submerged Macrophytes in Lakes. Springer-Verlag, New York.

Jupp, B. P., \& Spence, D. H. N. 1977. Limitation on macrophytes in an eutrophic lake, Loch Leven. I. Effects of phytoplankton. L. Ecol., 65, 175-186.

Kangur, M. 1998. Ülemiste järve kalastiku struktuur ja võimalused selle reguleerimiseks. Report manuscript. Estonian Marine Institute, Tallinn.

Leht, M. (ed.) 1999. Eesti taimede määraja. EPMÜ ZBI \& Eesti Loodusfoto, Tartu.

Mäemets, A. 1979. The macrophytes of Lake Ülemiste. Hydrobiol. Res., 8, 22-31 (in Russian).

Mäemets, A. 1984. 6. sugukond penikeelelised Potamogetonaceae Dumort. In Eesti NSV floora, Vol. 9 (Pärn, A. \& Rohtmets, M., eds), pp. 46-139. Valgus, Tallinn.

Mäemets, H. \& Mäemets, A. 2001. Macrophytes. In Lake Peipsi. II. Flora and Fauna (Pihu, E. \& Haberman, J., eds), pp. 9-22. Sulemees Publishers, Tartu.

Melzer, A. 1999. Aquatic macrophytes as tools for lake management. Hydrobiologia, 395/396, $181-190$.

Morgan, N. C. 1970. Changes in the fauna and flora of a nutrient enriched lake. Hydrobiologia, 35, 545-553.

Neuhaus, D., Kühl, H., Kohl, J.-G., Dörfel, P. \& Börner, T. 1993. Investigation on the genetic diversity of Phragmites stands using fingerprinting. Aquat. Bot., 45, 357-364.

Pork, M. 1968. Ülemiste järv. Taimestik. In Eesti järved (Mäemets, A., ed.), p. 442. Valgus, Tallinn.

Russow, E. 1862. Flora der Umgebung Revals. Archiv für die Naturkunde Liv-, Est- und Kurlands, 3, 2, 39-42.

Scheffer, M. 1998. Ecology of Shallow Lakes. Chapman \& Hall, London.

Schneider, G. 1908. Der Obersee bei Reval. Archiv für Biontologie, 2, 1, 38-55.

Suominen, J. 1968. Changes in the lake aquatic macro-flora of the polluted lake Rautavesi, S. W. Finland. Ann. Bot. Fenn., 5, 65-81.

Ter Heerdt, G. N. J. \& Drost, H. J. 1994. Potential for the development of marsh vegetation from the seed bank after a drawdown. Biol. Conserv., 67, 1-11.

Viljasoo, L. 1979. 43. selts kõrreliselaadsed Poales (Graminales). In Eesti NSV floora, Vol. 11 (Kuusk, V., Talts, S. \& Viljasoo, L., eds), pp. 22-479. Valgus, Tallinn.

Vinogradova, K. L., Gollerbach, M. M., Zauer, L. M. \& Sdobnikova, N. V. 1980. Guide to Freshwater Algae of the USSR, 13. Nauka, Leningrad (in Russian).

\title{
Suurtaimestik Ülemiste järves: muutused ja keskkonnafaktorite mõju
}

\author{
Tiiu Trei ja Tiia Pedusaar
}

Ülemiste järv on olnud Tallinna joogivee allikaks juba alates 14. sajandist, kuid veetöötlemist alustati 1927. a. Ülemiste järv on suures osas ühetaoline, madal, suhteliselt vähe liigendunud kaldajoonega ja peamiselt tasase lausa kaldaga, mistõttu on ka floristiline koosseis enamikus järvest sarnane. 2000. a uurimisandmeil kasvab kaldaid ääristavas taimedevöös vaid 9 liiki. Muust osast tugevasti erinevad, taimestikule teistsuguseid kasvukohti pakkuvad, ebatüüpilised kasvukohad (nt sissevoolavate ojade ja kanalite suudmealad) (joon 1) moodustavad 
järve pindalast ainult $0,9 \%$, kuid on märksa liigirikkamad. Kokku on järves loendatud 41 liiki.

Esimesed andmed Ülemiste järve taimestiku kohta pärinevad Russowilt (1862), kelle mahukas uurimus Tallinna ümbruse floorast sisaldab teavet ka Ülemiste järve kohta. Möödunud sajandil on Ülemiste suurtaimestikku uuritud neljal korral: 1908., 1968., 1979. ja 2000. a. Selgub, et Ülemiste oli juba saja aasta eest eutrofeerunud järv: muret tegi vee hägusus, mis oli tingitud väikesest sügavusest, paksust mudakihist järve põhjal ja planktonvetikate rohkusest.

Sajandi jooksul pole järve tüüpilises osas liigiline koosseis oluliselt muutunud, küll on aga muutunud suhted domineerivate liikide vahel (tabel 4). Praegu valitseb järves pilliroog, sellele järgneb järvkaisel, sajandi algul valitsenud rooghein on taandunud neljandaks. Taimedega kaetud ala pindala ja taimedevöö laius on vähenenud: selle põhjuseks on olnud suured veetaseme kõikumised sajandi algul ja sajandi teisest poolest alates toimunud veetaseme pidev tõus. 